Jurnal THEOREMS (The Original Research of Mathematics) Vol. 4 No. 2, Januari 2020. hal. 195-205

URL: http://jurnal.unma.ac.id/index.php/th

Naskah masuk: 22-12-2019 Naskah diperbaiki: 31-12-2019 Naskah diterima: 02-01-2020

\title{
ANALISIS SOAL UJIAN SEKOLAH BERSTANDAR NASIONAL MATEMATIKA SEKOLAH MENENGAH PERTAMA TAHUN AJARAN 2018/2019
}

\section{PROBLEM ANALYSIS OF MATHEMATICS NATIONAL-BASED SCHOOL EXAMINATION FIRST MIDDLE SCHOOL 2018/2019}

\author{
Irena P. L. ${ }^{*}$, Rika M. M. S.2, Ginda M. A. S3, Jarnawi Afgani ${ }^{4}$ \\ 1,2,3Pendidikan Matematika, Sekolah Pascasarjana UPI \\ ${ }^{4}$ Pendidikan Matematika, FMIPA, UPI, Bandung \\ E-mail:1'mrizki.fathoni82@gmail.com
}

\begin{abstract}
ABSTRAK
Ujian Sekolah Berbasis Nasional (USBN) merupakan program pemerintah dalam rangka melaksanakan evaluasi capaian kompetensi siswa yang dilakukan sekolah dan pengakuan atas prestasi belajar. Namun, proses pelaksanaan USBN dengan anggaran yang tidak sedikit ternyata belum se-ideal yang seharusnya. Aturan pembuatan soal USBN yang menyatakan bahwa 75\%$80 \%$ butir soal USBN dibuat oleh guru-guru atau tutor yang dikonsolidasikan Musyawarah Guru Mata Pelajaran (MGMP) menimbulkan pro-kontra, mengingat kualitas guru yang belum merata di Indonesia. Kualitas soal USBN pun dipertanyakan. Urgensi tersebut mendorong peneliti untuk melakukan analisis terhadap soal USBN, dengan tujuan meninjau kesesuaian soal USBN antara kisi-kisi yang sudah ditetapkan oleh pemerintah dengan butir soal USBN yang disusun oleh daerah (Kabupaten), meninjau kategori tingkat keterampilan berpikir pada soal USBN, dan meninjau prediksi obstacle siswa pada option pilihan ganda. Instrumen yang digunakan adalah kisi-kisi soal dan soal USBN Matematika Sekolah Menengah Pertama (SMP) salah satu kabupaten di Jawa Barat, pedoman kategori tingkat keterampilan berpikir siswa, serta pedoman wawancara. Metode penelitian ini adalah deskriptif kualitatif dan studi literasi. Hasil penelitian menunjukkan bahwa kualitas soal USBN belum optimal karena kisi-kisi USBN tidak sesuai dengan soal USBN, kategori tingkat keterampilan berpikir pada soal USBN masih didominasi oleh soal LOTS (indikator taksonomi Bloom).
\end{abstract}

Kata kunci: Kisi-kisi soal USBN, Soal USBN, Tingkat Keterampilan Berpikir

\section{ABSTRACT}

The National School-Based Examination (USBN) is a government program in the context of evaluating the achievement of student competencies conducted by schools and recognition of learning achievements. However, the process of implementing USBN with a budget that was not small turned out to be not as ideal as it should be. The rules for making USBN questions stating that $75 \%-80 \%$ of USBN items are made by teachers or tutors consolidated by the Subject Teachers' Consultation (MGMP) raises the pros and cons, given the teacher quality that is not evenly distributed in Indonesia. The quality of the USBN question was also questioned. The urgency encourages researchers to conduct an analysis of the USBN questions, with the aim of reviewing the suitability of the USBN questions between the gills set by the government and USBN items compiled by the regions (districts), reviewing categories of thinking skills level on USBN questions, and reviewing predictions student obstacle on multiple choice options. The instrument used was a grid of questions and questions USBN Mathematics Middle School (SMP) one of the 
Jurnal THEOREMS (The Original Research of Mathematics) Vol. 4 No. 2, Januari 2020. hal. 195-205

URL: http://jurnal.unma.ac.id/index.php/th

Naskah masuk: 22-12-2019 Naskah diperbaiki: 31-12-2019 Naskah diterima: 02-01-2020

districts in West Java, guidelines on the category of students' thinking skills level, as well as interview guidelines. This research method is a qualitative descriptive and literacy study. The results showed that the quality of the USBN question was not optimal because the USBN grid was not in accordance with the USBN problem, the category of thinking skills level on the USBN problem was still dominated by LOTS (Bloom's taxonomic indicator).

Keywords: USBN grid, USBN questions, Level of Thinking Skills 


\section{PENDAHULUAN}

Kompetensi lulusan peserta didik merupakan komponen yang menjadi fokus perhatian pemerintah pusat maupun daerah dalam bidang pendidikan. Salah satu cara untuk mengukur capaian kompetensi lulusan yaitu melalui sistem evaluasi baku yang ditetapkan secara nasional (UU Nomor 20 Th. 2003). Salah satu bagian dari sistem evaluasi pendidikan yaitu penilaian hasil belajar oleh satuan pendidikan dalam bentuk Ujian Sekolah Berstandar Nasional (USBN).

USBN adalah kegiatan pengukuran capaian kompetensi siswa yang dilakukan sekolah untuk seluruh mata pelajaran dengan mengacu pada standar kompetensi lulusan untuk memperoleh pengakuan atas prestasi belajar (POS Penyelenggara Ujian Nasional, 2018). USBN dilaksanakan di Indonesia mulai tahun 2017. Namun, pelaksanaan USBN faktanya memunculkan beberapa kontroversi dimulai dari anggaran yang tidak sedikit sampai penyelewengan pelaksanaan USBN dilapangan.

Anggaran pelaksaaan USBN tidaklah sedikit, dilansir dari halaman web jawapos, yakni sebesar kurang lebih 1,6 miliar di salah satu kota di Indonesia (Jawapos:Wulansari, 2019). Selain itu, berdasarkan informasi dari beberapa sekolah di Kabupaten Bandung, sekolah menganggarkan paling tidak 15 juta setiap tahunnya untuk pelaksanaan USBN.

Anggaran tersebut salah satunya dialokasikan untuk proses pembuatan soal USBN. Badan Standar Nasional Pendidikan (BSNP) tahun 2018 menyatakan bahwa sebanyak $75 \%-80 \%$ butir soal USBN disiapkan oleh guruguru atau tutor yang dikonsolidasikan Musyawarah Guru Mata Pelajaran (MGMP) dan dikoordinasikan oleh
Dinas Pendidikan Provinsi atau Dinas Pendidikan Kabupaten/Kota sesuai dengan kewenangannya.

Aturan pembuatan soal dari BNSP tersebut menimbulkan pro-kontra, mengingat kualitas guru yang belum merata di Indonesia. Pembuatan soal USBN oleh guru menurut pengamat pendidikan perlu dikaji ulang. Menurut Direktur Utama PT Eduspec Indonesia Indra Charismiadji, membiarkan guru membuat soal ujian sedangkan kualitas guru masih dipertanyakan, maka hasil penyusunannya pun sudah dapat diprediksi. Selain itu, aturan tersebut pada pelaksanaannya tidak se-idel yang diharapkan. Berdasarkan informasi dari salah satu guru berprestasi tingkat kabupaten yang juga merupakan anggota MGMP diketahui bahwa penyusunan soal USBN tidak melibatkan anggota MGMP melainkan hanya disusun oleh salah satu guru yang ditunjuk oleh pejabat berwenang.

Belum optimalnya kualitas soal USBN terjadi pada soal USBN IPA tahun 2017/2018. Menurut hasil penelitian Ishak, dkk (2018), untuk model logistik 2 parameter ( tingkat kesukaran dan daya beda), $42,86 \%$ butir soal USBN berkualitas baik, dan $57,14 \%$ berkualitas tidak baik (Ishak,dkk, 2018). Berdasarkan analisis butir soal ujian sekolah berstandar nasional dengan pendekatan klasik dan teori respon butir mapel matematika diperoleh sebagian besar butir tes pada kategori sukar.

Fakta yang terjadi terkait dengan USBN yang telah dipaparkan menimbulkan pertanyaan besar, "Apakah kualitas soal USBN Matematika SMP tahun ajaran 2018/2019 sudah optimal?" Hal ini menuntun peneliti untuk melakukan 
penelitian terhadap soal USBN Matematika tahun ajaran 2018/2019.

Berdasarkan latar belakang masalah, rumusan masalah penelitian ini adalah sebagai berikut.

a. Bagaimana kesesuaian antara kisikisi soal dengan soal USBN matematika SMP tahun ajaran 2018/2019?

b. Bagaimana kategori tingkat keterampilan berpikir pada soal USBN matematika SMP tahun ajaran 2018/2019?

c. Apakah pilihan jawaban yang tersedia pada soal pilihan ganda USBN sudah memperhatikan prediksi obstacle siswa?

\section{METODE PENELITIAN}

Penelitian dilaksanakan dengan metode deskriptif-kualitatif. Instrumen penelitian terdiri dari kisi-kisi soal dan soal USBN matematika tahun ajaran 2018/2019 dari salah satu SMP di Jawa Barat, pedoman kategori tingkat keterampilan berpikir siswa, dan pedoman wawancara. Langkah penelitian dimulai dengan studi leterasi, pengumpulan instrumen penelitian data, analisis kisi-kisi soal USBN Matematika, analisis kesesuaian butir soal USBN matematika terhadap kisikisinya, analisis kategori tingkat keterampilan berfikir pada soal USBN matematika, dan analisis pilihan jawaban yang tersedia pada soal pilihan ganda untuk melihat prediksi obstacle siswa. Hasil analisis dipaparkan dengan deskripsi hasil temuan.

3. HASIL DAN PEMBAHASAN

1) Hasil Analisis Kesesuaian Isi Soal USBN Matematika SMP Tahun Ajaran 2018/2019 Terhadap KisiKisi

Berdasarkan analisis kesesuaian isi soal USBN dan kisi-kisi soal USBN, ditemukan beberapa hal yang dianggap tidak sesuai. Perhatikan data pada kisikisi sebagai berikut.

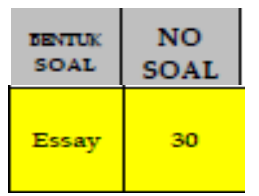

Berdasarkan kisi-kisi USBN, diketahui bahwa soal nomor 30 merupakan soal berbentuk uraian. Hal ini tidak sesuai dengan bentuk soal pada soal USBN sebagai berikut.

30. Data di satu kelas menunjukkan rata-rata berat badan siswa pria $40 \mathrm{~kg}$ dan rata-rata berat badan siswa wanita $31 \mathrm{~kg}$. Banyak siswa dalam kelas itu 36 siswa dan ratarata berat badan seluruh siswa 35 $\mathrm{kg}$. Kesimpulan yang benar dari informasi tersebut adalah ....

A. selisih banyak siswa pria dan wanita sembilan orang

B. banyak siswa pria dan wanita sama

C. siswa pria lebih banyak lima orang dari siswa wanita

D. siswa wanita lebih banyak empat orang dari siswa pria

Pada soal USBN jelas bahwa bentuk soal nomor 30 yaitu pilihan ganda. Hal ini mengindikasikan bahwa penyusun soal tidak teliti dan melakukan kecerobohan yang fatal. Ketidaktelitian tersebut juga terjadi pada bagian yang lainnya.

\begin{tabular}{|l|l|}
\hline Materi & Indikator Soal \\
\hline Sistem & Siswa dapat \\
persamaan & menyelesaikan \\
linear dua & permasalahan system \\
variabel & $\begin{array}{l}\text { persamaan linear satu } \\
\text { variabel }\end{array}$ \\
\hline
\end{tabular}


Jurnal THEOREMS (The Original Research of Mathematics) Vol. 4 No. 2, Januari 2020. hal. 195-205

Pada data di atas jelas terjadi perbedaan antara materi dan indikator soal. Pada materi dinyatakan sistem persamaan linear dua variabel, sedangkan pada indikator disebutkan system persamaan linear satu variabel. Kesalahan ini jelas ekstrim karena sistem persamaan linear dua variabel jelas berbeda dengan sistem persamaan linear satu variabel.

Ketidaksesuaian lainnya yang ditemukan dalam analisis yaitu sebagai berikut.

Kisi-kisi soal USBN:

\begin{tabular}{|l|l|}
\hline Materi & Indikator Soal \\
\hline $\begin{array}{l}\text { Operasi } \\
\text { bilangan }\end{array}$ & $\begin{array}{l}\text { Siswa dapat } \\
\text { menghitung operasi a } \\
\text { bulat }\end{array}$ \\
\hline
\end{tabular}

Soal USBN:

1. Hasil dari $(-20)+8 \times 5-18:(-3)$ adalah $\ldots .$.
A. -26
B. -14
C. 14
D. 26

Pada kisi-kisi tampak bahwa indikator soal ambigu. "Siswa dapat menghitung operasi..." bisa merujuk pada menghitung tanda operasi atau hasil operasi. Indikator sebaiknya diperjelas misalnya "Siswa dapat menentukan hasil operasi campuran dari ...". Selain itu, batasan untuk besaran bilangan bulat tidak dicantumkan dalam kisi-kisi, sehingga bisa menimbulkan perbedaan tafsir soal yang berakibat pada perbedaan tingkat kesukaran soal USBN di setiap daerah. Perhatikan contoh ketidaksesuaian lainnya.

Kisi-kisi soal USBN

\begin{tabular}{|l|l|}
\hline Materi & Indikator Soal \\
\hline $\begin{array}{l}\text { Aritmetika } \\
\text { Sosial }\end{array}$ & $\begin{array}{l}\text { Siswa dapat } \\
\text { menyelesaikan } \\
\text { perhitungan bunga } \\
\text { bank }\end{array}$ \\
\hline
\end{tabular}

Soal USBN:

4. Pak Joni menabung uang di bank sebesar Rp. 10.000.000,00 degan suku bunga $6 \%$ per tahun. Setelah beberapa bulan, uang Pak Joni menjadi Rp. 10.400.000,00. Lama Pak Joni menabung adalah...
A. 8 bulan
B. 10 bulan
C. 12 bulan
D. 14 bulan

Kisi-kisi dan soal USBN tersebut jelas tidak sesuai. Tujuan pada kisi-kisi yaitu siswa dapat menyelesaikan perhitungan bunga bank. Tetapi faktanya pada soal siswa diharapkan dapat menentukan lama waktu menabung. Ketidaksesuaian tersebut juga terjadi di beberapa bagian yang lainnya. Perhatikan data berikut.

Kisi-kisi soal USBN:

\begin{tabular}{|l|l|}
\hline Materi & Indikator Soal \\
\hline $\begin{array}{l}\text { Pola } \\
\text { barisan } \\
\text { bilangan }\end{array}$ & $\begin{array}{l}\text { Diberikan pola bilangan, } \\
\text { siswa dapat } \\
\text { menentukan pola } \\
\text { tertentu }\end{array}$ \\
\hline
\end{tabular}

Soal USBN:

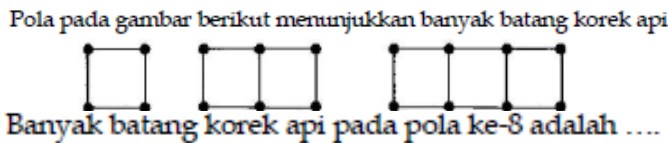

A. 19 batang

B. 22 batang

C. 25 batang

D. 28 batang

Pada kisi-kisi soal dinyatakan bahwa diberikan pola bilangan, siswa dapat menentukan pola tertentu. Tetapi pada soal yang diberikan adalah barisan objek bukan barisan bilangan. Kemudian yang ditanyakan justru 
banyak batang korek api. Hal ini jelas menunjukan ketidaksesuaian antara sesuatu yang ingin diukur dengan alat ukurnya. Indikator bisa diubah misalnya menjadi "Diberikan barisan objek, siswa dapat menentukan suku tertentu berdasarkan pola tertentu". Hal yang sama juga terjadi pada data berikut.

Kisi-kisi soal USBN:

\begin{tabular}{|l|l|}
\hline Materi & Indikator Soal \\
\hline Analisis & Diberikan gambar foto \\
masalah & menempel pada karton \\
lesebangu & sehingga sebangun, \\
nan & siswa dapat \\
& menganalisis besarab- \\
& besaran yang belum \\
& diketahui dan dapat \\
& menyelesaikannya \\
\hline
\end{tabular}

Soal USBN:

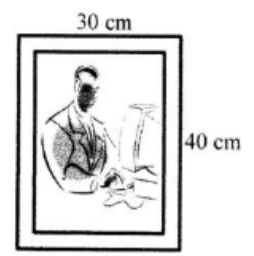

34. Sebuah foto ditempelkan pada karton seperti pada gambar. Di sebelah kiri dan kanan foto terdapat karton masing-masing selebar $3 \mathrm{~cm}$. Sedangkan atas dan bawah foto belum diketahui ukurannya. Foto dan karton sebangun. Pertanyaan:

a. Buatlah sketsa gambar dengan ukurannya

b.Buatlah persamaann perbandingan ukuran foto dengan ukuran karton untuk menghitung panjang foto!

c. Hitunglah luas karton yang tidak tertutup foto dengan menentukan luas karton dan luas foto!
Kekeliruan terletak pada sebuah indikator yang direalisasikan menjadi tiga butir pertanyaan. Sebaiknya indikator dipecah saja menjadi tiga indikator sesuai dengan pertanyaan pada soal yaitu bagian a. b. Dan c. Kesalahan lain juga tampak pada soal bagian a. Siswa diminta untuk membuat sketsa gambar dengan ukurannya tetapi pada soal sendiri sketsa gambar sudah disediakan oleh penyusun soal. Hal ini menjadi sesuatu yang tidak efektif dan tepat sasaran. Kesalahan juga terjadi pada data berikut.

Kisi-kisi Soal USBN:

\begin{tabular}{|l|l|}
\hline Materi & Indikator Soal \\
\hline Menyajikan & Diberikan gambar \\
dan & diagram, siswa dapat \\
mendeskripsik & mendeskripsikan \\
an data & $\begin{array}{l}\text { besaran dari diagram } \\
\text { tersebut }\end{array}$ \\
\hline
\end{tabular}

\section{Soal USBN:}

35. Perhatikan gambar berikut!

Banyak pengtunjung perpustakaan sekolah selama 5 hari disajikan pada grafik. Tentukan rata-rata pengunjung $\mathrm{F}$

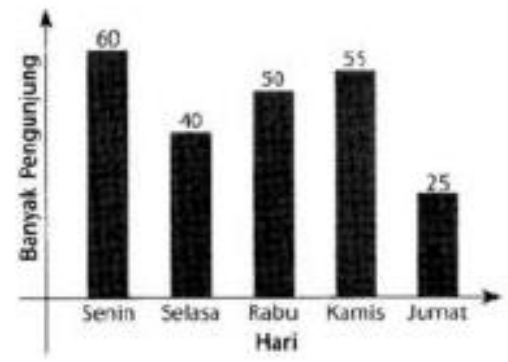

Berdasarkan data tersebut jelas bahwa indikator soal tidak sesuai dengan realisasi soal. Pada soal tidak ada sama sekali bagian yang memberikan kesempatan kepada siswa untuk mendeskripsikan, siswa hanya diminta untuk menghitung rata-rata dari diagram batang yang disediakan. Hal ini sangat mudah mengingat nilai 
data pada diagram pun sudah dituliskan oleh pembuat soal.

Berdasarkan uraian dari analisis yang telah dilakukan, diketahui bahwa penyusun soal melakukan beberapa kesalahan seperti tidak teliti dalam menentukan bentuk soal, tidak menyusun indikator soal dengan jelas, tidak teliti dalam menyesuaikan materi dan indikator soal, serta tidak cermat dalam merealisasikan indikator soal ke dalam soal. Hal tersebut mengakibatkan terjadinya ketidaksesuaian isi soal USBN dan kisi-kisi soal USBN. Berdasarkan perhitungan persentase hasil analisis, diketahui bahwa paling tidak 28,57\% kisi-kisi USBN tidak sesuai dengan soal USBN. Hasil tersebut tentu mengkhawatirkan mengingat dana besar yang digelontrkan dan harapan pemerintah yang sangat tinggi terhadap USBN sebagai alat ukur capaian kompetensi siswa.

\section{2) Hasil Analisis Kategori Tingkat Keterampilan Berpikir Pada Soal USBN Matematika SMP Tahun Ajaran 2018/2019 \\ Analisis kategori tingkat} keterampilan berpikir pada soal USBN yang dilakukan pada penelitian ini didasarkan pada kategori soal Low Order Thinking Skill (LOTS) dan High Order Thinking Skill (HOTS). Pengkategorian ini menggunakan dua indikator. Indikator pertama yaitu taksonomi Bloom yang terdiri dari mengingat, memahami, dan mangaplikasikan untuk ranah LOTS, dan menganalisis, mengevaluasi, serta mencipta untuk ranah HOTS (Anderson \& Krathwohl, 2016; Ariyana, Pudjiastuti, Bestary, \& Zamroni, 2018).

Indikator kedua yaitu indikator ranah soal HOTS dengan kriteria stimulus atau banyak menggunakan rangsangan untuk menginduksi keterampilan inferensi dan kritik, multiple layers of thought yaitu menggabungkan ranah kognitif untuk dampak yang lebih besar, unfamiliar contex yaitu memaksa siswa untuk benar-benar berpikir, tidak dengan mudah mengingat materi yang dibahas di kelas, dan real-life situation yaitu menantang siswa untuk menggunakan pembelajaran dari berbagai disiplin ilmu untuk dipecahkan, dan non repetitive yaitu tidak berulang (Mohamed \& Lebar, 2017).

Berdasarkan hasil analisis, terdapat beberapa perbedaan pengkategorian tingkat keterampilan berpikir antara pembuat soal dengan peneliti. Pengkategorian pada kisi-kisi soal terdiri dari:

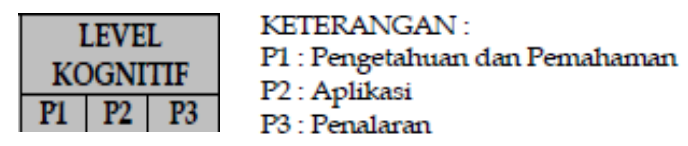

Pada kisi-kisi soal, diketahui bahwa ranah P1 adalah pengetahuan dan pemahaman. Hal ini cukup menarik perhatian karena dua indikator berada pada P1. Berdasarkan nalar, ketika P1 diterjemahkan ke dalam bentuk soal maka target kompetensi yang ingin dicapai pada siswa menjadi ambigu, apakah targetnya ranah pengetahuan saja, ranah pemahaman saja, atau keduanya. Hal tersebut tentu menciptakan ketidakjelasan.

Selanjutnya, terdapat juga ketidaksepahaman antara pembuat soal USBN dengan peneliti dalam menentukan kategori tingkat keterampilan berpikir siswa. Perhatikan contoh berikut.

Kisi-kisi soal USBN:

\begin{tabular}{c|c|c|c|c}
\multicolumn{2}{c|}{ LEVEL } & \multirow{2}{*}{ EENTUK } & NO \\
KOGNITI & SOAL & SOAL \\
\hline P1 & P2 & P3 & & \\
\hline & & $\sqrt{n n n}$ & PG & 17 \\
\hline
\end{tabular}


Soal USBN:

17. Jika 5 merupakan salah satu akar persamaan $2 x^{2}+x+c=0$, maka akar yang lain dari persamaan tersebut adalah ....
A. -6
C. -5
B. $-5,5$
D. $-4,5$

Berdasarkan pengamatan peneliti, soal tersebut tidak termasuk ke dalam kategori P3. Soal tersebut hanya terbatas mengingat materi, memahami konsep, dan mengaplikasikan konsep untuk menyelesaikan soal (P2 pada kisi-kisi).

Perbedaan lainnya terletak pada persentase banyaknya soal USBN yang tergolong LOTS dan HOTS. Menurut pembuat soal, dilihat dari data pada kisi-kisi soal, yang termasuk ke dalam kategori soal LOTS yaitu sebanyak 5 butir soal atau $14,29 \%$, dan sisanya sebanyak 30 soal atau $85,71 \%$ termasuk kategori soal HOTS. Data tersebut tersaji pada diagram berikut.

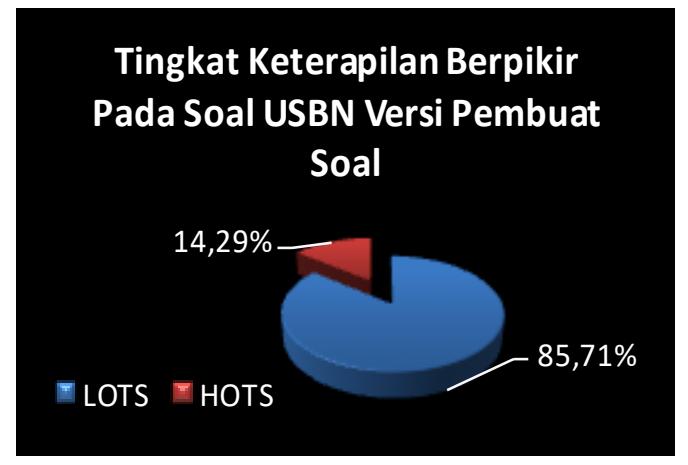

Berbeda sedikit dengan analisis peneliti, persentase banyaknya soal USBN yang tergolong soal LOTS berdasarkan indikator Bloom yaitu 31 soal atau $88,57 \%$ dan 4 soal atau $11,43 \%$ tergolong soal HOTS. Data tersebut tersaji pada diagram berikut.

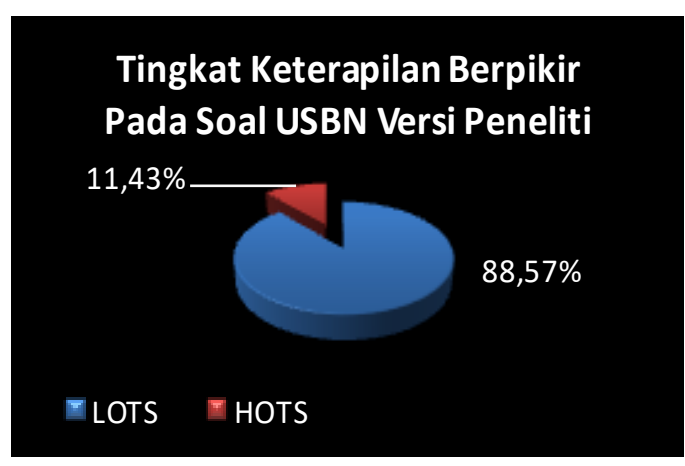

Adapun salah satu soal yang dianggap masuk pada kategori HOTS berdasarkan indikator taksonomi Bloom yang dianalisis oleh peneliti yaitu sebagai berikut.

7. Bakteri akan membelah diri menjadi dua setiap 30 menit. Jika mula-mula ada 25 bakteri, maka banyak bakteri selama 4 jam adalah .....
A. 3.000
B. -3.200
C. 6.000
D. 6.400

Pada proses pemecahan masalah pada soal nomor 7 siswa tentu harus menganalisis soal mengenai pembelahan bakteri terkait dengan waktu. Setelah itu siswa harus mengevaluasi hasil analisisnya untuk menciptakan pola tertentu dari pembelahan bakteri tersebut. setelah pola ditemukan kemudian siswa mengingat mengenai keterkaitan hasil yang diciptakannya dengan konsep materi yang dimilikinya sampai akhirnya siswa paham dan mengaplikasikan konsep tersebut untuk menyelesaikan soal.

Selanjutnya, berdasarkan indikator stimulus, multiple layers of thought, unfamiliar contex, real-life situation, dan non repetitive, soal yang dianggap masuk 
pada kategori HOTS yaitu sebanyak 3 soal atau $8,57 \%$, sisanya 32 soal atau 91,43\% termasuk pada kategori LOTS yang terpecah pada 3 soal memberikan stimulus saja, 1 soal memberikan stimulus dan multiple layers of thought, dan 28 soal tidak memberikan kelima unsur indikator tersebut. data tersebut tersaji pada diagram berikut.
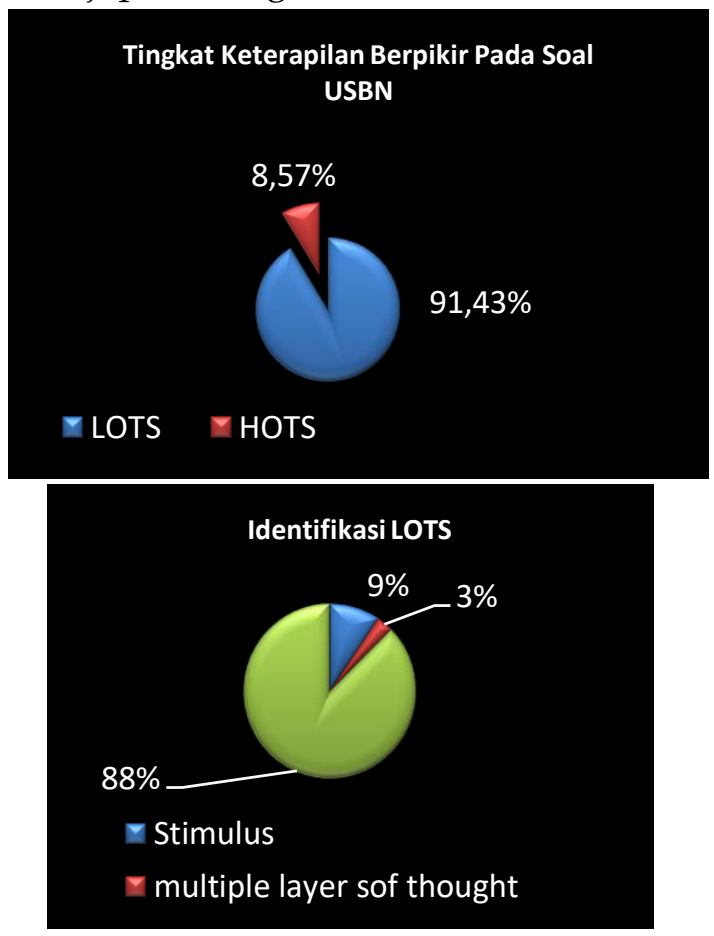

Adapun salah satu soal yang dianggap masuk pada kategori HOTS berdasarkan indikator stimulus, multiple layers of thought, unfamiliar contex, real-life situation, dan non repetitive, yaitu sebagai berikut.

24. Trianto membuat bangtun dengan cara menumpuk kubus-kubus kecil seperti pada gambar. Bangun tersebut dicat seluruh bagian luarnya. Banyak kubus kecil yang terkena cat pada satu sisinya saja adalah....
A. 8
B. 18
C. 24
D. 30

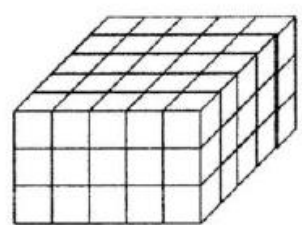

Pada soal tersebut tampak diberikan sebuah stimulus berupa gambar dengan pengecatan bersyarat yang meranngsang siswa untuk kritis. Soal tersebut juga memiliki multiple layers of thought karena siswa harus mengetahui konsep sisi kubus, tetap harus mengaitkan konsep tersebut dengan proses pengecatan bersyarat. Konteks soal tersebut juga unfamiliar, menuntut siswa untuk berpikir dengan teliti terhadap syarat yang ditetapkan. Selanjutnya mengenai real-life situation, jelas soal tersebut menyangkut permasalahan sehari-hari seperti pengecatan batu bata hias untuk dinding, dan non repetitive karena jarang ditemukan soal semacam ini.

Berdasarkan uraian sebelumnya jelas diketahui bahwa kategori tingkat keterampilan berpikir pada soal USBN matematika smp tahun ajaran 2018/2019 masih didominasi oleh soal LOTS. Hal ini tidak sesuai dengan target kurikulum yang menitikberatkan pada perkembangan HOTS. Berdasarkan analisis peneliti, terdapat beberapa faktor yang menyebabkan minimnya soal HOTS pada soal USBN tersebut. faktor tersebut diantaranya yaitu faktor kisi-kisi soal, sebaran materi, dan guru.

Pertama, faktor kisi-kisi soal USBN. Pada kisi-kisi soal, tampak HOTS memang bukan menjadi target penilaian. Hal ini terlihat dari target kognitif yang mayoritas hanya berkisar antara P1 dan P2 sebanyak 30 soal. Adapaun P3 hanya diwakili oleh 5 soal yang menurut peneliti masih terlalu mudah untuk soal berstandar nasional.

Kedua yaitu faktor sebaran materi. Menurut analisis peneliti, sebaran soal kurang diperhatikan dengan baik oleh penyusun. Terdapat beberapa materi dengan bahasan yang sama tetapi mempunyai tingkat kognitif yang sama pula. Misalnya pada bahasan persamaan kuadrat dan bangun ruang 
sisi lengkung yang masing-masing terdiri dari 2 soal, dimana kedua soalnya sama-sama masuk pada kategori LOTS. Sebaiknya, materi dalam satu bahasan dengan frekuensi lebih dari satu soal, paling tidak mempunyai tingkat kognitif yang bervariasi.

Terakhir yaitu faktor guru. Berdasarkan hasil penyebaran kuesioner HOTS pada beberapa guru, diketahui bahwa sebagian guru yang diberi kuesioner belum menguasai tentang konsep HOTS. Misalnya tidak semua guru memahami mengenai taksonomi Bloom. Hal ini terbukti dari jawaban guru seperti berikut.

1. Apakah anda mengetahui tentang taksonomi Bloom atau Anderson? Jika Ya jelaskan
Taksonomi Bloom: Tahapan berpikir mulai dari pengetahuan,
pemanaman, aplikaś, analisis, sintesis dan evaluati.
Selain itu, beberapa guru juga
mempunyai persepsi yang salah
mengenai kriteria soal HOTS. Soal
HOTS dianggap sebagai soal yang sulit.
4. Bagaimana ciri alat evaluasi (soal) HOTS yang anda ketahui?
Sult

Terakhir, soal HOTS belum dibiasakan penerapannya oleh sebagian guru dalam kegiatan pembelajaran.

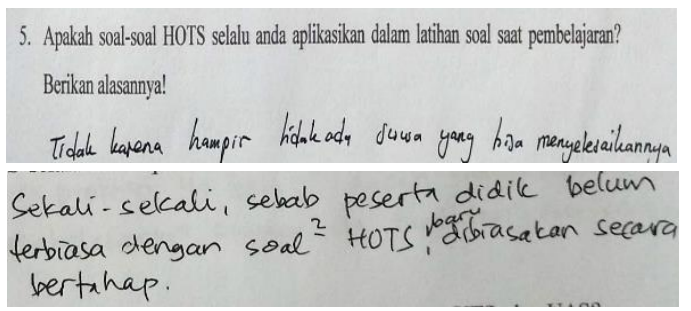

4. KESIMPULAN

a. Kisi-kisi USBN tidak sesuai dengan soal USBN

b. Kategori tingkat keterampilan berpikir pada soal USBN masih didominasi oleh soal LOTS

c. Pilihan jawaban yang tersedia pada soal pilihan ganda belum memperhatikan prediksi obstacle siswa

\section{SARAN}

Saran untuk pembaca artikel ini: sebaiknya dilakukan analisis lanjutan dari soal USBN ditinjau dari ketercapaian siswa dalam keterampilan berpikir dari masing masing materi uji nya, atau dari peninjauan lainnya.

\section{DAFTAR PUSTAKA}

Anderson, \& Krathwohl. (2016). Bloom's Taxonomy Revised. Leslie Owen Wilson.

Ariyana, Y., Pudjiastuti, A., Bestary, R., \& Zamroni. (2018). Buku pengangan pembelajaran beroriantasi pada keterampilan berpikir tingkat tinggi. Jakarta: Direktorat Jenderal Guru da Tenaga Kependidikan Kementerian Pendidikan dan Kebudayaan.

Maharani, Esthi dan Gumanti A. (2018). Pengamat: Pembuatan Soal USBN Oleh Guru Perlu Dikaji. Repbublika.co.id. Akses: 21 Desember 2019

Mohamed, R., \& Lebar, O. (2017). Authentic Assessment in Assessing Higher Order Thinking Skills. International Journal of Academic Research in Business and Social Sciences, $\quad 7(2)$, 466-476. https://doi.org/10.6007/IJARBSS /v7-i2/2021

\{Krathwohl, D. R.2001. A revision of Bloom's Taxonomy: an overview Theory Into Practice, College of Education, The Ohio State University Pohl. 2000. Learning to think, thinking to learn: ( tersedia di www.purdue.edu/geri diakses 20 November 2019).

Peraturan Menteri Pendidikan \& 
Jurnal THEOREMS (The Original Research of Mathematics) Vol. 4 No. 2, Januari 2020. hal. 195-205

URL: http://jurnal.unma.ac.id/index.php/th

Naskah masuk: 22-12-2019 Naskah diperbaiki: 31-12-2019 Naskah diterima: 02-01-2020

Kebudayaan Republik Indonesia

No. 5 Tahun 2015 Tentang Kriteria

Kelulusan Peserta Didik,

Penyelenggaraan Ujian Sekolah/

Madrasah/ Pendidikan Kesetaraan

pada SMP/MTs atau yang sederajad dan SMA/MA/SMK atau yang sederajat. $11 \mathrm{hlm}$.

Peraturan Menteri Pendidikan \& Kebudayaan Republik Indonesia No. 23 Tahun 2016 Tentang Standar Penilaian Pendidikan. $12 \mathrm{hlm}$. Permendikbud 2013. Penilaian. Jakarta: Kementerian Pendidikan dan Kebudayaan.

Sappaile, Basi Intan dan Triyanto P. (2019). Analisis Butir Soal Ujian Sekolah Berstandar Nasional dengan Pendekatan Klasik dan Teori Butir Mata Pelajaran Matematika. Makasar: Proseding Seminar Nasional LP2M UNM2019. ISBN: 978-623-7496-14-4 